\title{
The Electoral Effectiveness of Constituency Campaigning in the 2010 British General Election: The 'Triumph' of Labour?'
}

\author{
Justin Fisher (Brunel University), David Cutts (University of Manchester) \& Edward \\ Fieldhouse (University of Manchester)
}

\begin{abstract}
This paper establishes a model of likely campaign effectiveness, before examining the intensity of constituency campaigning at the 2010 General Election in Britain and its subsequent impact on electoral outcomes, using both aggregate and individual level data. It shows that constituency campaigning yielded benefits in varying degrees for all three main parties and that Labour's constituency campaign efforts were effective despite the electoral context, and ultimately affected the overall outcome of the election. These findings have significant implications for our understanding of the circumstances under which campaigns are likely to be more or less effective, and provide further evidence that a carefully managed campaign stands the most chance of delivering tangible electoral payoffs.
\end{abstract}

Keywords: Campaigning; Political Parties; 2010 General Election; Britain; Campaign Management; Electoral Impact

\section{Introduction - The growing importance and potential for campaign effects}

In studies of the past few elections, a broad consensus has developed to suggest that election campaigning may be electorally effective in Britain (Clarke et al, 2004, 2009; Whiteley \& Seyd, 1994; Pattie, et al., 1995; Denver et al., 2003). Indeed, there are several contextual effects that heighten the potential for campaign payoffs. First, the strength of partisan identification in Britain has declined in intensity, and to a lesser extent in overall volume though the core of fairly strong partisans has remained relatively constant (see Figure 1). Secondly, voter hesitancy has increased (see Figure 2). In 2010, fully $37 \%$ of respondents to the British Election Study post-election survey indicated that they had made their decision on how to vote during the campaign, with a further $13 \%$ indicating that their decision had been taken since the turn of the year. Given that all parties engage in 'longterm' campaigning - especially in target seats (Fisher \& Denver, 2008) - there would appear to be significant potential at least for constituency campaigning to be electorally significant. Thirdly, while voters may indeed make electoral judgements ostensibly exogenous to campaigning, long-term party campaigning could theoretically act to some degree as a preference shaper of voter judgements, which, as Clarke et al (2011) show, have become increasingly important in voters' choices.

Research for this paper was funded by the Economic and Social Research Council. Grant Number RES-000-222762. This support is gratefully acknowledged 
Some sceptics, however, point out that few voters change their minds as a result of campaigns. Rather, reinforcement is the most likely outcome. Consequently, it is argued that this may suggest the relative unimportance of campaigns (see, for example, Holbrook, 1996: 613). This argument however, is flawed for two reasons. First the mobilisation of supporters by a party to turn out to vote can make a large impact on their vote share. Second, although counter-factual and not observable, failure to campaign might result in loss of votes for a party. The observed change in party support hides the impact on those who were persuaded to stick with their party of choice. Thus the down-playing of reinforcement makes no logical sense: vote switching may be easier to measure, but the cementing of voter choice is just as significant.

Beyond these broader contextual factors the importance and potential electoral impact of campaigning is now widely accepted at the constituency level. Three different research teams have repeatedly demonstrated the electoral benefits that can accrue from wellorganised and intense election campaigns at constituency level in Britain, despite using different methodological approaches and measures of campaign strength (see, for example Whiteley \& Seyd, 1994; Pattie, et al., 1995; Denver et al., 2003). Moreover, work combining the different methods of measurement of campaign effort, has shown that all three major parties directed their resources to target and more marginal seats in the 2005 election, and this additional effort was rewarded both in boosting the party's vote and reducing its opponent's vote (Fieldhouse and Cutts, 2008).

1.1 In this paper we seek to measure the electoral impact of the three main British parties' campaigns at the 2010 election (Conservative, Labour and the Liberal Democrats). Aggregate data are drawn from a survey of all electoral agents of the five major parties in Great Britain - the Conservatives, Labour, Liberal Democrats, Plaid Cymru and the Scottish National Party $(\mathrm{N}=1,993) .{ }^{2} 1,079$ valid responses were received - an overall response rate of $54 \%$. Details of responses by party are shown in the Appendix. These illustrate a representative spread of constituencies. In order to confirm this, however, means were compared in respect of candidate spending (percentage of maximum spent) during the regulated long and short campaigns. For all parties, the results indicate that our sample is robust (see Appendix). In addition, in depth interviews were conducted with the parties at national level, as well as with agents in constituencies selected on the basis of their electoral status. We also use individual level data from the British Election Study's Campaign Internet Panel Survey to confirm the patterns observed in our aggregate level data.

As is customary, no candidates from the major parties (in this case, Labour and the Liberal Democrats) contested the seat of the Speaker. 
Figure 1. Partisan Identification 1964-2010

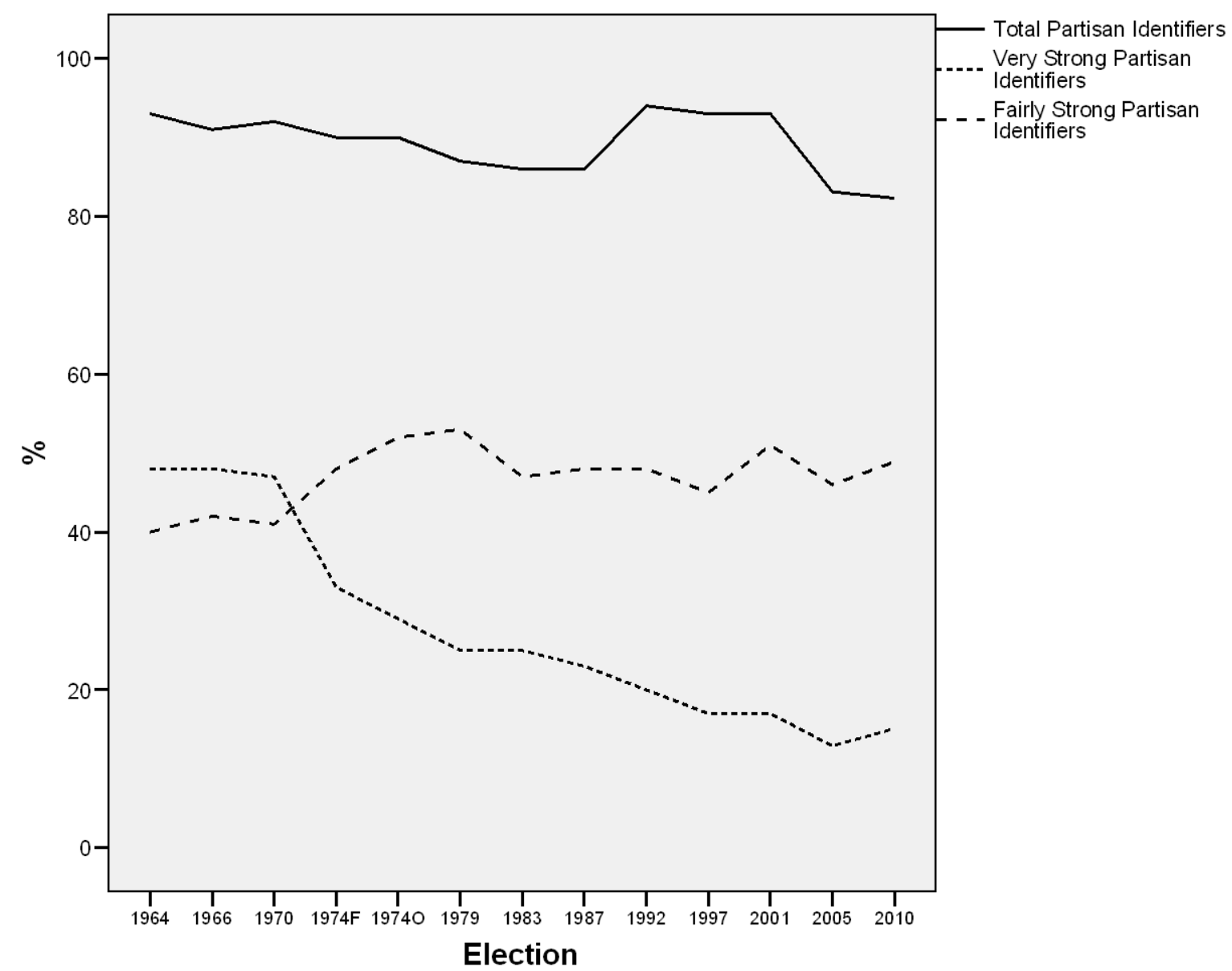

Source: British Election Study 
Figure 2. Late Deciders 1964-2010

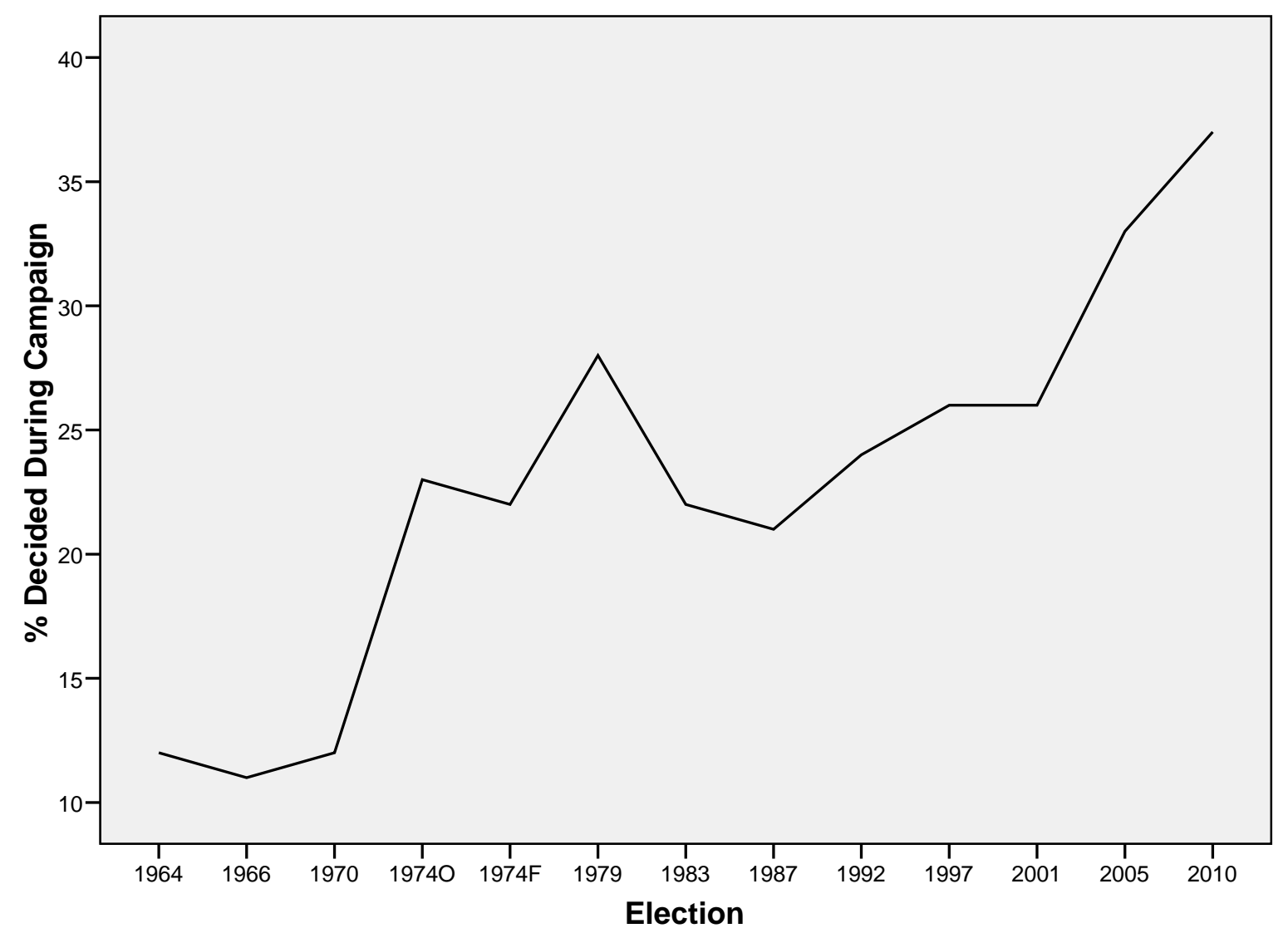

Source: British Election Study 


\section{The Electoral Context}

Notwithstanding these more general observations, previous research on the impact of constituency campaigns has demonstrated how the extent the electoral impact will vary by electoral context. Broadly speaking, three patterns emerge. First, the competitiveness of an election will have a bearing on the level of electoral impact - tight elections (such as the British election of 1992) will generally lead to stronger electoral campaigns and a greater impact of those campaigns. Second, elections where significant change is anticipated maybe even critical elections (such as the British election of 1997) - are likely to produce more effective campaigns - particularly for the principal challenger. Thirdly, successful constituency campaigns are partly a function of good central coordination (Fisher et al., 2006a). Coordination is better achieved when there are fewer target seats, and so campaigns will tend to be more effective when there are fewer seats to target. For example, in the 2001 election, both Labour and the Conservatives' campaigns were generally less effective, in part because they were targeting so many seats (Denver et al., 2002a).

In addition to these factors, campaigns will also be affected in part by the 'national mood'. We would expect that campaigns are likely to be less effective when a party is unpopular and on the defensive, thereby creating conditions where voters are less receptive to a party's campaign. An example of this is 2005 , when Labour campaigning, despite being well organised, had significantly less impact compared with previous elections (Fisher et al., 2005). Other research using experimental methods has also shown that campaign interventions are affected by the level of popularity of the party (Niven, 2001; Hillygus, 2005; Arceneaux and Nickerson, 2009). In other words (and not surprisingly) overall party popularity in the run-up to an election may matter to campaign effectiveness.

Overall, the effectiveness of campaigns for all parties should be stronger when the parties are reasonably popular. We refer to this as popularity equilibrium. In other words, parties may not be equally popular (else the election could theoretically result in a tie) but that no parties are especially unpopular - there is, in effect, a normal state of affairs in terms of the relative popularity of the parties. Under the conditions of popularity equilibrium, targeting a large number of seats is likely to lead to less effective campaigning. However, where one or more parties are very unpopular, the effects of targeting a large numbers of seats may be partially reversed for the more popular party. Equally, a tight election (bearing in mind that electoral outcomes are a function of changes in seat shares, which may not closely reflect aggregate votes shares) should generate equally effective campaigning under the conditions of popularity equilibrium, but not where one or more parties is relatively unpopular. We can summarize these expected outcomes in Table 1. 
Table 1. Exogenous factors influencing likely effectiveness of constituency campaigns

\section{Closeness of Election \\ Significant change likely \\ High No's of Target seats}

\author{
More Effective \\ Popularity Equilibrium \\ Challenger(s) \\ Unpopular party(ies)
}

\section{Less Effective}

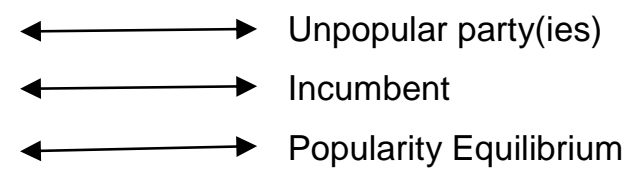

The 2010 election was one where all of these ostensibly exogenous factors were important to some extent. First, the election was increasingly tight. The Conservatives' 17-point poll lead in previous September 2009 had been significantly reduced on the back of increasing economic optimism and a growing view that the incumbent party had handled the economic crisis well, coupled with concerns about the likely impact of significant cuts in the event of a Conservative victory (Clarke et al, 2011). By the time the election was called in early April 2010, the Conservative lead was around 8-9 points. Coupled with that, the poll rating of the Liberal Democrats increased significantly at particular points during the short campaign (though it also fell back as polling day approached). Together with the effects of the electoral system (which have tended to favour Labour in recent elections), the outcome of the election remained unclear during much of the campaign. Second, it was evident nevertheless that some significant change was on the horizon. At the very least, it was plain that thirteen years of Labour majority rule were coming to an end. Beyond that, there were a number of possibilities, including either a Conservative minority or majority administration (few predicted a coalition). For those reasons, we might have expected constituency campaigning to be more effective for the challengers

On the other hand, the electoral arithmetic suggested that parties' powers of coordination would be stretched. The Conservatives needed to win 116 seats just to gain a majority of one. This would have represented the third largest number of gains in the post-war period, bettered only by the landslide victories of 1945 and 1997 (the next largest number of gains was 67 in 1970). The Liberal Democrats too had many more seats to target. In the first instance, there was the large number of their own seats to defend. Unfortunately for the Liberal Democrats, few can normally be regarded as being truly 'safe' - particularly with a resurgent Conservative Party. Second, the Liberal Democrats' success in winning some seats from Labour in 2005 meant that there were opportunities to increase their number of seats further, particularly with Labour being relatively unpopular. In addition, Labour found itself seeking to defend seats from a number of parties in order to minimise its losses. Labour knew it would lose seats. The key issue was ensuring that it did not lose too many. 
All in all, this meant that all parties were potentially stretched in terms of effectively coordinating their efforts at constituency level.

Overall, these factors would have suggested the following in terms of the likely effectiveness of their constituency campaigns: the Conservatives had advantages under all three conditions of the election's closeness, the likelihood of change and the number of targets. In all three, the relative unpopularity of Labour made conditions more favourable for the Conservatives. However, while Labour was unpopular, the Conservatives were not themselves overwhelming popular, thus tempering their advantage. Labour's unpopularity meant that it was at a disadvantage across all three exogenous factors. Finally, the Liberal Democrats had distinct advantages. The party was relatively popular and despite targeting relatively large numbers of seats, was advantaged by Labour's unpopularity and the Conservatives' less robust standing.

\section{Target Seats and Targeting Strategies}

All three parties, as would be expected, had target seats and specific targeting strategies. What has emerged, however, over recent elections is not so much a binary measure of whether or not a seat is a target, but particular categories of target seat status. There is an overall group of seats which are identified as targets, but the emphasis placed upon different sub-groups may not be identical - at least at central party level from where much direct mail is distributed (Fisher et al, 2011). Each of the three main parties identified a large number of seats to target, but within that group of seats there were divisions - very much like a football league - and the intention was that in seats within certain key divisions there would be more intense campaigning.

Positioning within these divisions was not entirely fixed - depending on political and electoral circumstances, some seats were moved in or out of the core groups (Fisher et al, 2011). For example, following the Liberal Democrat boost and Labour's decline in the opinion polls following the leaders' debates (Pattie \& Johnston, 2011), the Conservatives sought to switch their efforts from Liberal Democrat marginals to those seats where the party now thought it could more realistically challenge Labour. Of course, a shift in emphasis mid-campaign may be easier to accomplish in terms of the distribution of direct mail and telephone voter identification at a national level (Fisher, 2010). At local level, such a shift in emphasis will be more difficult to accomplish quickly.

The Conservatives identified around 160 seats within four divisions. The 'premier league' consisted of 38 seats, and were ones the party expected to gain without significant effort. 
These were described as 'certainties' More important were the first and second divisions ('core targets' and 'possibles') - seats the party would need to focus upon if it was to have any chance of power. The third division ('hopefuls') consisted of seats that were within the party's range, but which the party would only be likely to win if the electoral picture was going very well. Labour had 145 targets overall. It, too, had four divisions of seats devised on a sophisticated basis according to electoral circumstances as well as levels of party activity (Fisher et al, 2011). Not surprisingly, the seats were almost always ones that the party was defending with differing expectations as to the likelihood of success. The Liberal Democrats had a comparatively large number of target seats, including all their own seats plus a further 37 (mainly Labour-held) seats that the party hoped to gain: 99 in total. Thus, there were two divisions - defensive and offensive.

\section{Overall Campaign Intensity}

Overall campaign intensity is best illustrated by the creation of an index, which incorporates all of the core components of a constituency campaign: preparation, organisation, manpower, use of computers, use of telephones, polling day activity, use of direct mail, level of doorstep canvassing, and leafleting (see, for example, Denver \& Hands, 1997),. In this paper, we initially utilize two scales. First, the scale developed first in the 2001 study of constituency campaigning, which provides a good, comprehensive picture of campaign intensity (the 2001 scale). Second, we develop a new scale, which incorporates new measures first utilized in the 2010 study, which capture developments in e-campaigning (see Fisher et al, 2011). The intensity indexes are calculated using a Principal Components Analysis (PCA) of all these core indicators of constituency campaigning. ${ }^{3}$ Using conventional cut-off criteria, the PCAs suggest one factor is sufficient to represent the variance in the original variables in both of the indexes (details of which are shown in the Appendix). The PCAs produce factor scores which are then standardised around a mean of 100 . This process allows easy comparisons between parties as well as the target status of seats. The difference between the scores incorporating e-campaigning and those that do not are marginal. For information, we list both scores here, but the subsequent multi-variate analyses are conducted using the broader 2010 index (which includes e-campaigning). ${ }^{4}$

4.1 The first step is to evaluate the distribution of campaign intensity by party and by target status. There are three categories: Targets (seats which a party is seeking to gain or defending, often with a small majority), Held Not Target (seats that party holds comfortably),

Where there were missing data on individual variables that formed part of these scales, multiple imputation was used, which took account of the individual party and the target status of the seat.

The Campaign Intensity scales were calculated using responses from all five parties in the survey. However, only the scores for the Conservatives, Labour and Liberal Democrats are shown in this paper. 
and Not Held Not Target (seats in which the party has very little chance of winning). Parties that fail to target their resources effectively are less likely to generate positive electoral payoffs overall. Thus, we would expect parties as far as possible to distribute their resources such that target seats should have the most intense campaigns and 'hopeless' seats, the least intense. By and large, we would also expect seats that parties hold, but which are not targets to score somewhere in between, in part because safe seats tend to have higher levels of membership or local resources (Fisher, 2000; Fisher et al., 2006b).

Table 2 illustrates the mean campaign index scores for each party overall and then by seat status. First, it is clear that the Conservatives had the strongest campaigns overall, with the Liberal Democrats having the weakest of the three largest parties. However, overall strength only tells part of the story. What is more important is that the strongest campaigns take place in the target seats. As Fisher and Denver (2008) have shown for example, while the Liberal Democrats have always been much weaker overall, they have been very successful in fighting their strongest campaigns where they were needed most, and therefore moving to a level of campaign development that is on a par with that of the Conservatives, despite the significant disparity in overall resources (see also Fieldhouse and Cutts, 2008). Table 2 illustrates that the Liberal Democrats were again successful in this respect, the intensity of the campaigns in their target seats being slightly higher than that of Labour and equal to that of the Conservatives. Nevertheless, this represents something of a change for the Conservatives, who have historically struggled to focus their efforts effectively. Indeed, perhaps the principal surprise is the relative strength of Conservative campaigning in its hopeless seats (Not Held, Not Target) - possibly reflecting the enthusiasm of Conservative supporters in an election where the party had a realistic chance of overall victory. Elsewhere, the results are pretty much as expected for the other parties (with the means for all categories being statistically significant from each other).

Table 2. Campaign Intensity by Party and Target Status (2001 Scale in Parenthesis)

\begin{tabular}{lrrrr}
\hline & All & $\begin{array}{r}\text { Held Not } \\
\text { Target }\end{array}$ & Target & $\begin{array}{r}\text { Not Held Not } \\
\text { Target }\end{array}$ \\
\hline Conservative & $112(112)$ & $118(119)$ & $140(140)$ & $92(91)$ \\
Labour & $100(100)$ & $116(117)$ & $131(132)$ & $76(76)$ \\
Liberal Democrat & $91(90)$ & $*$ & $140(140)$ & $82(82)$ \\
\hline
\end{tabular}

4.2 Given that the parties had divisions of target seats, however, it is also interesting to see if the distribution of campaign effort varied in more detail. For each of the main parties, 
we compare the mean distribution on campaign intensity across the various internally determined categories of seats. The differences in the means are not statistically significant (though they are compared with non-targets). They do, however, provide suggestive evidence of some differentiation in terms of campaign effort. Figure 3 examines Conservative seats, and the distribution is almost exactly as one might predict. The level of campaign intensity in the 'certainties' or the 'premier league' was higher than in non-targets, but not as high as in the 'core targets' (or division one). In the next set of targets, campaigning is a little lower than the certainties, while the long shots or 'hopefuls' had the least intense campaigns among the target seats. If we examine Labour (Figure 4), we observe a significant difference between targets and non-targets, and a progressive increase in intensity from the most vulnerable seats to the more defendable (up to the penultimate category) - suggesting a very defensive strategy by Labour. In the case of the Liberal Democrats (Figure 5), the difference between targets and non-targets is very clear. However, what is slightly surprising is that the intensity of campaigning was almost identical in Liberal Democrat seats as it was in its offensive targets (seats that the party hoped to gain). All in all, these figures suggest that there was some variation at constituency level in the intensity of campaigning in different target seats, but not as much as might have been predicted at national level, suggesting that such variation is difficult to manage with as much precision at local level.

Figure 3. Conservative Campaign by Detailed Target Status

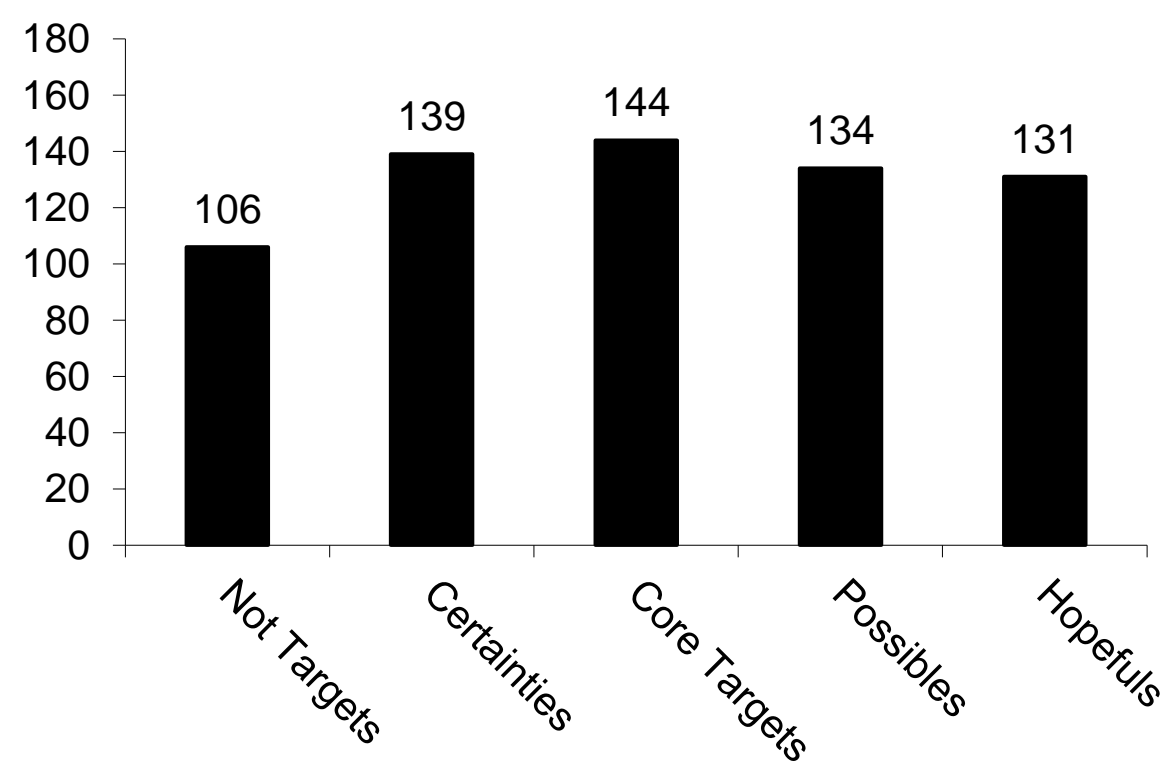


Figure 4. Labour Campaign by Detailed Target Status

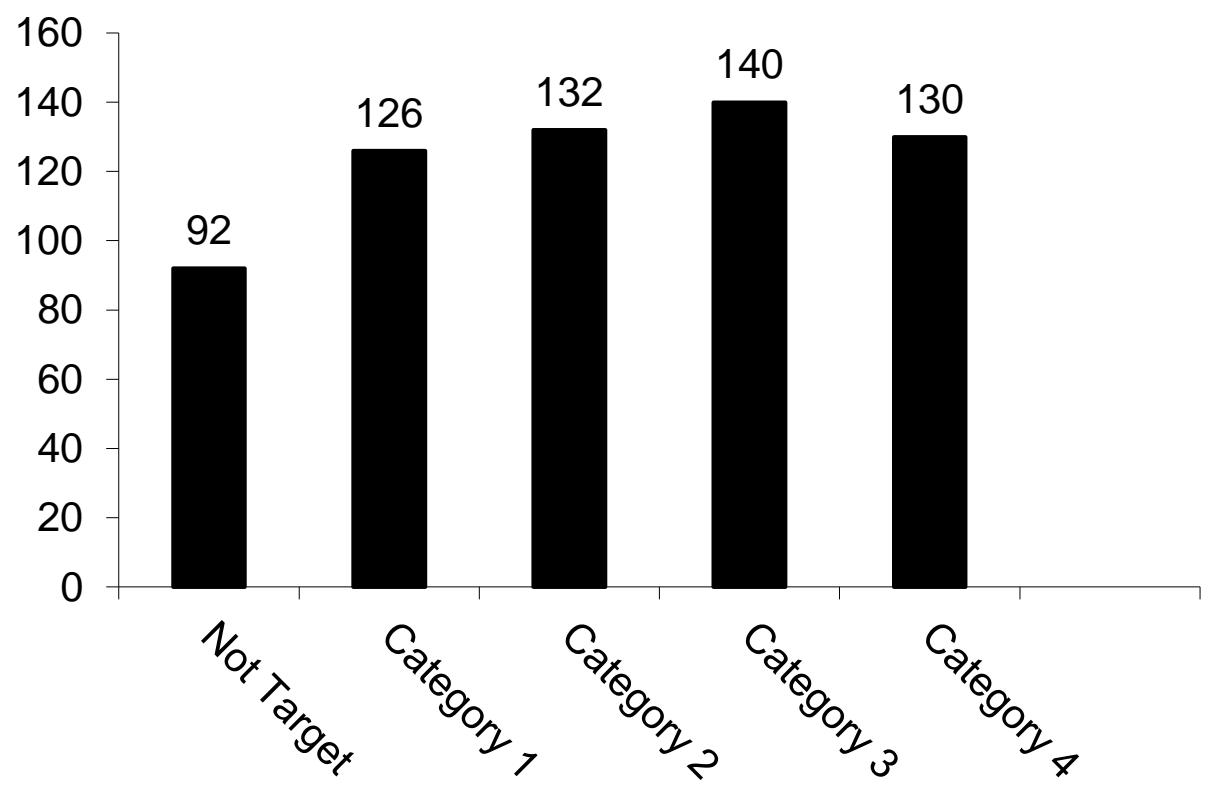

Figure 5. Liberal Democrat Campaign by Detailed Target Status

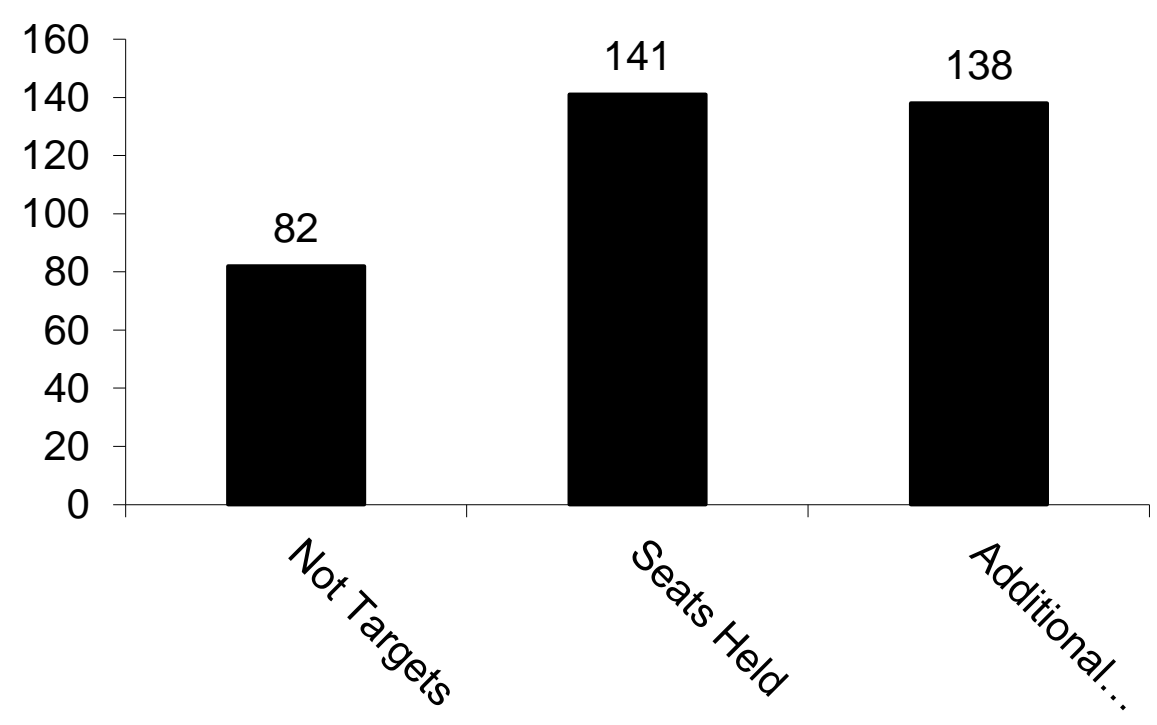

\section{The Electoral Impact}

In Table 3, we examine the estimated electoral impact of constituency campaigning by each of the main three parties using ordinary least squares regression (OLS). On account of extensive boundary revisions in England and Wales, we are unable to estimate impact on the preferred dependent variable of share of the electorate as no robust data on 'notional electorates' for 2005 are available. Instead, share of the vote is used. The model we employ is straightforward. Each party's share of the vote in 2010 is regressed on the campaign intensity index, controlling for 'notional' share of the vote in 2005 (data for which are robust), and personal incumbency. The use of the notional share of the vote in 2005 as a control 
makes the model a dynamic test and also ensures that other variables that are correlated with previous vote, such as demographics, are effectively controlled. In addition, previous vote share will also capture previous campaign efforts. Thus, insofar as campaign efforts are correlated over time, the true extent of campaign effects may actually be under-estimated. The test is a stiff one - not surprisingly, previous vote share captures a great deal of the variance, so the model provides a robust first test of whether or not constituency campaigning made a positive and significant contribution to vote shares at this election.

For each party, it is apparent that more intense constituency campaigning did indeed appear to yield electoral payoffs, though the impact varies a little, with Liberal Democrat campaigning having the greatest impact. For example, the model suggests that a Liberal Democrat candidate (non-incumbent) whose campaign reached the average intensity of a Liberal Democrat target seat (140 from Table 2) could expect to win $35.4 \%$ of the vote compared to a similar candidate with a campaign intensity of a non-target seat (82) who would win $31.7 \%$ of the vote. The difference of $3.7 \%$ suggests a reasonable boost in vote for those Liberal Democrat candidates running a strong campaign. The equivalent figures for the Conservatives are $39.1 \%$ (campaign intensity 140) and $38.3 \%$ (campaign intensity 92) suggesting a difference of less than one percent. These results represent both change and continuity with previous studies of constituency campaigning (Denver \& Hands, 1997; Denver et al, 2002a, 2003; Fisher et al, 2005). In respect of the Liberal Democrats, there is continuity. The party's seemingly effective targeting policy once again meant that local campaigns did yield tangible payoffs in addition to the positive effects of personal incumbency. In the case of the Conservatives, while its campaigning effects were the weakest of the three main parties, there is further evidence that the party has continued to improve in the way it conducts constituency campaigning such that is now seemingly electorally effective. In previous elections, the party has periodically suffered from the fact that while it was running strong campaigns overall, the resources in campaigns were often insufficiently well focussed upon where they were required most.

Labour's result is, however, perhaps the most surprising. Given the importance of electoral context, we would have expected that Labour campaigning would be less effective, given that there was a widespread expectation that the party would lose majority rule, that it was required to target so many seats, and that it was unpopular and on the defensive. However, the results here suggest that faced with defeat and the prospect of a Conservative government or even losing second place to the Liberal Democrats, local Labour campaigns proved to be more effective than might have been imagined. Despite controlling for vote share in 2005 and some fairly substantial personal incumbency effects, Labour's 
constituency campaigning still yielded electoral payoffs. A Labour candidate (non-incumbent) whose campaign reached the average intensity of a Labour target seat (131) could expect to win $1.65 \%$ more of the vote share than a candidate with a campaign intensity of a non-target seat (intensity 76).

Table 3. The Impact of Constituency Campaigning on Share of the Vote 2010

\begin{tabular}{|c|c|c|c|c|c|}
\hline \multirow[b]{2}{*}{ Constant } & \multicolumn{2}{|c|}{ Conservative } & \multirow{2}{*}{$\begin{array}{c}\text { Labour } \\
-6.728(.920)^{* *}\end{array}$} & \multicolumn{2}{|c|}{ Lib Dems } \\
\hline & 2.290 & $(.705)$ ** & & 1.231 & $(.701)$ \\
\hline Vote Share 2005 & .987 & $(.020) * *$ & $.896(.023) * *$ & .723 & $(.032) * *$ \\
\hline Incumbent & .866 & $(.557)$ & $2.706(.699)$ ** & 3.078 & $(.991) * *$ \\
\hline Campaign Intensity & .016 & $(.007) *$ & $.030(.010) * *$ & .064 & $(.009) * *$ \\
\hline Adj. $R^{2}$ & .955 & & .901 & .861 & \\
\hline
\end{tabular}

Note 1: Coefficients are unstandardised $b$ values. Standard Errors in parenthesis Note $2:{ }^{* *} p<.01{ }^{*} p<.05$

5.2 The results in Table 3, however, only tell us so much since of course, campaigns do not occur in isolation - other parties are also campaigning in constituencies and thus the optimal outcome of any one party's campaign is not only to enhance its share of the vote, but also to damage that of other parties. A further analysis is therefore required, which includes constituencies where we have campaign intensity scores for all three parties. Inevitably, this results in a reduction in the number of available cases and so it is here, where we have 102 constituencies with full scores for the Conservatives, Labour and the Liberal Democrats.

The application of OLS is, however, not necessarily appropriate for the analysis of vote shares in multi-party elections for three main reasons (Cutts and Shryane, 2006; Cutts and Webber, 2010). First, vote shares between two parties are negatively correlated - yet OLS models lack an appreciation of these substitution effects. Second, and related to the first reason, an assumption of OLS is that the residuals of separate models are uncorrelated. The residuals would be positively correlated because in constituencies where party vote share is higher than predicted by the model at least one of the other parties must be weaker than predicted, leading to large residual variances in both equations (Cutts and Shryane, 2006; Cutts et al, 2007). Using an OLS approach would ignore this correlation and could produce inefficient estimates. Thirdly, a party's vote share is bounded between 0 and 100 per cent. OLS predictions, however, are unbounded and are based on continuous data which follow normal distributions. Consequently, using OLS models it is possible to generate vote share estimates that are either negative or greater than 100 per cent. 
To combat the potential problems of using OLS regressions when analysing multi-party vote shares, a number of scholars have proposed using a method that is based upon the Seemingly Unrelated Regression (SUR) modelling technique (Katz and King, 1999; Tomz et al, 2002; Cutts and Shryane, 2006). To deal with the problem of unbounded predicted values, party vote shares are converted into vote share ratios using a logistic transformation. After the selection of a party as the reference category the natural log of the vote share ratio between it and other parties is obtained, thereby mapping bounded vote share values (i.e. $0-100$ percent) onto an unbounded $(-\infty$ to $+\infty)$ vote share ratio measure. Non-independence is therefore dealt with in SUR by specifying equations (one for each of the dependent variables) to be jointly modelled and allowing the error terms to be correlated across equations (Cutts and Shryane, 2006). The selection of the party base category enables differences in vote shares between that party and another party to be analysed. For example, in Table 4 below where Labour and Liberal Democrat vote share is the base category, the equation can be written as follows:

$$
\begin{aligned}
& \operatorname{In}\left(\operatorname{Con}_{i} / \operatorname{Lab}_{i}\right)=X \beta_{i 1}+\varepsilon_{i 1} \\
& \operatorname{In}\left(\text { LibDem }_{i} / \operatorname{Lab}_{i}\right)=X \beta_{i 2}+\varepsilon_{i 2} \\
& \ln \left(\operatorname{Con}_{i} / \operatorname{LibDem}_{i}\right)=X \beta_{i 1}+\varepsilon_{i 1} \\
& \ln \left(\operatorname{Lab}_{i} / \operatorname{LibDem}_{i}\right)=X \beta_{i 2}+\varepsilon_{i 2}
\end{aligned}
$$

where $\varepsilon$ is the residuals for each constituency that are correlated across equations (e.g. $\varepsilon_{i 1}$ and $\varepsilon_{i 2}$ within the equation), $X$ is a set of independent explanatory variables and $\beta$ is a set of coefficients to be estimated. The equations (1-2) stated above do not include where the Conservatives are the base category and this would be needed for a comprehensive estimation. ${ }^{5}$ However for ease of interpretation, we provide the results where Labour is the base category and include the Conservative-Liberal Democrat comparison where the latter is the reference to show the differences in vote shares between all the main parties. ${ }^{6}$

\footnotetext{
5 Theoretically, there appears to be an inverted duplication in the dependent variables with, for example, $\ln \left(\mathrm{LD}_{i} / \mathrm{Lab}_{i}\right)$ and $\ln \left(L_{a b} / L D_{i}\right)$. However, such an assertion is incorrect as the estimation of these two dependent variables is based on the simultaneous estimation of two other different dependent variables. As the errors will be correlated in different ways then the coefficients will be different too. Nevertheless, the quantitative estimates of explanatory variable coefficients for seemingly identical dependent variables will be highly correlated and similar in magnitude. But empirically, they will not necessarily be the same.

In Table 4, we provide the vote share differences between the main parties and not the results from the full set of base categories necessary for comprehensive estimation. However, the full results of the SUR model where 1) the
} 
Table 4 (Model 1 and 2) shows the SUR model of where Labour is the reference category and the natural log of the vote share ratio between it and the other two parties as the dependent variables. Negative coefficients indicate an increase in Labour support compared with the Conservatives and the Liberal Democrats because Labour vote share is the denominator in the ratio-dependent variable. Here we show the results of two models - with and without party support in the previous election. In both models, we ran the BreuschPagan test to assess whether the residuals were uncorrelated across equations. The highly significant results indicate the violation of OLS assumptions and the justification for using the SUR approach.

In Models 1 and 2, Labour campaigning, as measured through the campaign intensity index, had a significant impact and improved the Labour vote against both that of the Liberal Democrats and the Conservatives. Liberal Democrat campaigning was effective in improving its relative vote share against Labour, while Conservative campaigning had no significant impact on its performance when compared against Labour once previous vote share is controlled for. Personal incumbency again mattered for Labour. Where the Labour candidate was an incumbent the party significantly improved its vote against both rival parties even after controlling for previous support. No such personal incumbency effects were evident for the Conservatives or the Liberal Democrats against Labour when previous support was included in the model.

Table 4 (Model 3) shows the SUR model of where the Liberal Democrats is the reference category. Liberal Democrat campaigning, as measured through the campaign intensity index, had a significant impact and improved the Liberal Democrat vote against the Conservatives, while Conservative campaigning had no significant impact on its performance relative to the Liberal Democrats when previous vote share is included. Labour campaigning did have a negative impact on the Liberal Democrat vote suggesting that Labour campaign intensity improved the Conservative vote at the expense of the Liberal Democrats. Where the Conservatives stood the same candidate as in the previous election, their vote significantly improved when compared against the Liberal Democrats. Personal incumbency effects were not evident for the Liberal Democrats or Labour.

There is one caveat to these multi-party results. By necessity, we can only use cases where we have responses for all three parties. Perhaps inevitably, the distribution of those cases is

Liberal Democrats are the base category against Labour; 2) the Conservatives are the base category against Labour and the Liberal Democrats; 3 ) Other parties are the base categories is available from the authors on request. 
not as representative as where we are only using data from only one party. Thus, in our 102 cases that we are able to use for the SUR modelling, there is an over-representation of safer seats. Given that the Conservatives were on the offensive and Labour was on the defensive, there is a possibility therefore that our SUR results may overestimate the impact of Labour campaigns and underestimate that of the Conservatives. That said, the single party analyses and the individual-level analyses (see section 5.3) produce similar patterns to the SUR results, suggesting that whatever the limitations of the distribution of our case in the SUR analyses, that the broad findings are still robust.

Overall, these findings are consistent with the results from previous studies (Denver \& Hands, 1997; Denver et al, 2002a, 2003; Fisher et al, 2005). Labour and Liberal Democrat campaigning at constituency level tends to be more effective than that of the Conservatives. However, what is particularly noteworthy are the results for Labour. Once again, what emerges from these data is that Labour campaigns were successful against the odds and it is thanks to them in part that Labour's losses were not nearly as great as might have been expected. All of this begs the question as to why electoral context did not appear to necessarily exert influence in ways that might be expected. The election was tight and change was expected, yet it was Labour and the Liberal Democrats whose campaigns were most effective, with Labour's campaigning being effective despite its defensive stance and relative unpopularity.

Table 4: SUR Model of Party Support in the 2010 General Election

\begin{tabular}{|c|c|c|c|c|c|c|}
\hline Variables & $\begin{array}{l}\text { Model } 1 \\
\text { Lab-LD }\end{array}$ & $\begin{array}{l}\text { Model } 1 \\
\text { Lab-Con }\end{array}$ & $\begin{array}{c}\text { Model } 2 \\
\text { Lab-LD }\end{array}$ & $\begin{array}{c}\text { Model } 2 \\
\text { Lab-Con }\end{array}$ & $\begin{array}{l}\text { Model } 3 \\
\text { LD-Con }\end{array}$ & $\begin{array}{l}\text { Model } 3 \\
\text { LD-Con }\end{array}$ \\
\hline Constant & -.273 & .262 & .456 * & .580 & .535 * & .015 \\
\hline Conservative Campaign Intensity & .003 & .008 & .002 & .001 & $.005 *$ & -.000 \\
\hline Labour Campaign Intensity & $-.011 *$ & -.010 & $-.007 *$ & -.003 & .001 & .003 \\
\hline Lib Dem Ca & $.009 *$ & .002 & .003 & -.000 & $-.007 *$ & -.002 \\
\hline abent & $.539 *$ & .716 & .108 & .108 & $.177 *$ & .114 \\
\hline Labour Incumbent & $-.408 *$ & -.790 & $-.232 *$ & -.152 & $-.382 *$ & -.022 \\
\hline Lib Dem Incumbent & $.757 *$ & .084 & -.173 & -.090 & $-.673 *$ & .191 \\
\hline Lab-LD 200 & - & 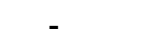 & $.755 *$ & . & - & 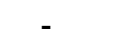 \\
\hline Lab-Con 2005 Vote Ratio & - & & & .953 & - & - \\
\hline LD-Con 2005 Vote Ratio & & & & - & & $.824 *$ \\
\hline & .76 & .70 & .90 & .96 & .54 & .83 \\
\hline $\mathrm{RM}$ & .466 & .573 & .303 & 217 & 340 & 211 \\
\hline Number of Observations & 102 & 102 & 102 & 102 & 102 & 102 \\
\hline
\end{tabular}

* Significant $5 \%$ level

Model 1: Breusch-Pagan Test of Independence: $\operatorname{chi2}(1)=65.995, \operatorname{Pr}=0.0000$

Model 2: Breusch-Pagan Test of Independence: chi2(1) $=45.391, \operatorname{Pr}=0.0000$

Model 3: Breusch-Pagan Test of Independence: $\operatorname{chi2}(1)=25.982, \operatorname{Pr}=0.0000$ 


\subsection{Individual Level Analysis}

So why was Labour so apparently successful in terms of its constituency campaigning? One explanation is that Labour was successful in persuading 'late deciders' to vote for the party. We test this proposition using the British Election Campaign study, examining the ultimate vote choices made by respondents who initially declared themselves to be undecided in terms of which party to support in the pre-campaign survey, conducted just before the beginning of the campaign 'proper' at the end of March/beginning of April 2010. We then examine whether they were contacted by the parties and if so, in how many different ways they were contacted by each party over the course of the campaign. The British Election Study featured questions about eight different forms of party contact both during and immediately before the campaign (doorstep, telephone, in the street, leaflets, email, text, Twitter/Facebook or other). A scale was constructed of all these items for party to capture campaign intensity - more forms of contact being a surrogate for more intense campaigning. Of course, some of these forms of contact could include contacts from the national party rather than as a result of local efforts (especially leaflets or telephone calls), and voters would be unable to distinguish between the source of such contacts (local and national). However, given that we know that local and national campaigns are themselves increasingly integrated (Fisher \& Denver, 2008), these individual data still therefore provide us with the opportunity to confirm the patterns found in our aggregate data which focus exclusively on local effort.

Tables 5, 6 and 7 show the results of our individual level analyses by party voted for in 2010 . Our analyses are cross-sectional, having selected voters who were undecided in terms of vote choice prior to the campaign. This is so we can isolate the effect of the campaign on those who had not already made up their mind. We use binary logistic regression with the dependent variable being coded as a vote for a particular party or not (i.e. Vote Conservative 1 , Not Vote Conservative 0 ). We fit three models each with additional control variables. Model 1 examines the impact of the campaigns on undecided voters without any controls. Model 2 controls for previous vote for the party that the respondent ultimately chose. Including previous vote as a control helps remove any possible effects of endogeneity similar to including previous vote share in the constituency level analyses. This effectively controls for the possibility that parties send more campaign material to people who have supported the party previously (measured by previous vote).

In order to further test the robustness of our results, we estimate with a third model (Model 3), which includes the additional controls of which party was deemed to have the best policies to solve the respondent's assessment of the most important problem (MiP) facing 
the country; Clarke et al, $(2004,2009,2011)$ show how this assessment has been a critical determinant of voting behaviour in the last three elections. These are, therefore useful further control variables to confirm the impact of our variables of interest - the campaigns. Of course issue performance is itself likely to be influenced by the campaign, so the inclusion of these as independent variables may lead to an underestimation of the campaign's effects. However it is useful to run the models with the additional controls to provide a lower bound on the campaign effects ${ }^{7}$. What is clear from the results in Model 3 , however, is that despite the additions of these controls, the results in respect of the campaign effects remain unchanged

Some important patterns are apparent in the analyses. First, Labour campaigning exerted a statistically significant positive impact on the Labour vote amongst undecided voters, and a negative impact on votes for other parties in all three models. For example, using the results from Model 2, ${ }^{8}$ a previously undecided voter who had voted Labour in 2005 and had received three types of Labour campaign material and only one from the other two main parties, had a 0.63 probability (or $63 \%$ chance) of voting Labour (see Figure 6). This compares with only a probability of 0.29 for an otherwise identical voter receiving no Labour campaign material (and one from the other major parties). The equivalent percentages for undecided electors who had not voted Labour previously were $24 \%$ and $7 \%$ respectively. In relative terms the differential between those receiving material and those not was greater for Labour than the other parties (although in absolute terms the Liberal Democrat campaign attracted more new undecided voters). Equally, undecided voters were significantly less likely to ultimately vote Conservative after receiving more Labour contacts, even if they had voted Conservative in 2005.

The same patterns are also true for the Liberal Democrats. As can be seen in Figure 6, the Liberal Democrats were ultimately the most voted for party amongst undecided respondents, Moreover, campaign contacts significantly boosted the chances of voting Liberal Democrat while reducing the chances of voting for other parties amongst previously undecided voters. For example, the model predicts $84 \%$ of undecided voters who had voted Liberal Democrat previously and had received three types of Liberal Democrat campaign material (and one

We ran a further model including evaluations of the three main party leaders following Clarke et al's (2004, 2009, 2011) demonstration of the importance of leadership effects on vote choice. Due to a large number of missing values, this resulted in an unacceptable loss of 173 cases. We include the model in the Appendix (see Table A1), nevertheless, for information. The results are broadly unchanged, except for the fact that the negative impact of Conservative campaigning of the Labour vote, and Labour campaigning on the Conservative vote are now nonsignificant. However, our view is that these changes can be explained by the fact that evaluations of leaders are themselves influenced by the campaign (see, for example, Stevens, Karp \& Hodgson, 2011). Campaigning will, by its very nature, seek to influence leadership evaluations (especially in a campaign so dominated by leaders - see Pattie \& Johnston, 2011; Stevens, Karp \& Hodgson, 2011).

Model 2 is preferred for the estimation of predicted values due to the possible endogeneity of issue performance. However, using model 2 or model 3 makes very little difference to the size of the effects. 
from the other major parties) would vote Liberal Democrat compared with $59 \%$ for a similar voter receiving no Liberal Democrat campaign material. For the Conservatives, however, the results are a little less strong. On the one hand, a higher level of Conservative contact had the effect of both boosting the chances of voting Conservative and lessening the chance of voting Labour amongst previously undecided voters. Greater exposure to Conservative campaigns (defined in the same way) led a predicted $71 \%$ of undecided Conservatives to vote for the party again in 2010 compared to $52 \%$ who were not subject to any campaign contact. Similarly the Conservative campaign reduced the chance of undecided voters choosing Labour. However, Conservative campaign contacts had no impact on Liberal Democrat support. In all three models, the impact of Conservative contacts on Liberal Democrat voting was non-significant.

Table 5. The Impact of Campaign Contacts on Previously Undecided Voters (Conservative Vote)

\begin{tabular}{|l|rl|rl|rr|}
\hline$n=3221$ & \multicolumn{2}{|c|}{ Model 1 } & \multicolumn{2}{|c|}{ Model 2 } & \multicolumn{2}{|c|}{ Model 3 } \\
& \multicolumn{2}{|c|}{$\mathrm{B}$} & $\mathrm{B}$ & $\mathrm{B}$ \\
\hline Con Campaign & .391 & $(.067)$ & .274 & $(.073)$ & .297 & $(.083)$ \\
Lab Campaign & -.302 & $(.080)$ & -.238 & $(.087)$ & -.241 & $(.096)$ \\
Lib Dem Campaign & -.271 & $(.082)$ & -.209 & $(.088)$ & -.223 & $(.097)$ \\
Con Vote 2005 & $\mathrm{n} / \mathrm{a}$ & & 2.130 & $(.108)$ & 1.752 & $(.119)$ \\
Con MiP & $\mathrm{n} / \mathrm{a}$ & $\mathrm{n} / \mathrm{a}$ & & 1.720 & $(.123)$ \\
Lab MiP & $\mathrm{n} / \mathrm{a}$ & $\mathrm{n} / \mathrm{a}$ & -1.443 & $(.218)$ \\
Lib Dem MiP & $\mathrm{n} / \mathrm{a}$ & $\mathrm{n} / \mathrm{a}$ & -1.333 & $(.198)$ \\
Constant & -1.167 & $(.054)$ & -1.597 & $(.063)$ & -1.572 & $(.075)$ \\
Nagelkerke $\mathrm{R}^{2}$ & .021 & & .198 & & .351 & \\
-2 Log likelihood & 3456.694 & & 3047.826 & & & \\
\hline
\end{tabular}

Note1: Standard Errors in parenthesis

Note 2: n/a Not Applicable

Note 3: MiP Most Important Problem

Table 6. The Impact of Campaign Contacts on Previously Undecided Voters (Labour Vote)

\begin{tabular}{|l|rl|rl|rr|}
\hline$n=3221$ & \multicolumn{2}{|c|}{ Model 1 } & \multicolumn{2}{|c|}{ Model 2 } & \multicolumn{2}{|c|}{ Model 3 } \\
& \multicolumn{2}{|c|}{$\mathrm{B}$} & \multicolumn{2}{|c|}{$\mathrm{B}$} & $\mathrm{B}$ \\
\hline Con Campaign & -.272 & $(.077)$ & -.231 & $(.082)$ & -.199 & $(.086)$ \\
Lab Campaign & .563 & $(.073)$ & .471 & $(.079)$ & .462 & $(.082)$ \\
Lib Dem Campaign & -.491 & $(.091)$ & -.392 & $(.095)$ & -.451 & $(.102)$ \\
Lab Vote 2005 & $\mathrm{n} / \mathrm{a}$ & & 1.655 & $(.091)$ & 1.430 & $(.096)$ \\
Con MiP & $\mathrm{n} / \mathrm{a}$ & $\mathrm{n} / \mathrm{a}$ & & -1.143 & $(.205)$ \\
Lab MiP & $\mathrm{n} / \mathrm{a}$ & $\mathrm{n} / \mathrm{a}$ & 1.284 & $(.116)$ \\
Lib Dem MiP & $\mathrm{n} / \mathrm{a}$ & $\mathrm{n} / \mathrm{a}$ & -.835 & $(.171)$ \\
Constant & $-1.190 \quad(.054)$ & -1.920 & $(.076)$ & -1.875 & $(.085)$ \\
Nagelkerke R & .039 & & .190 & .286 & \\
-2 Log likelihood & 3360.551 & & 3013.008 & & 2772.558 & \\
\hline
\end{tabular}

Note1: Standard Errors in parenthesis

Note 3: n/a Not Applicable

Note 3: MiP Most Important Problem 
Table 7. The Impact of Campaign Contacts on Previously Undecided Voters (Liberal Democrat Vote)

\begin{tabular}{|c|c|c|c|c|c|c|}
\hline$n=3221$ & $\begin{array}{r}\text { Mode } \\
\mathrm{B}\end{array}$ & & $\begin{array}{r}\text { Mode } \\
\mathrm{B}\end{array}$ & & $\begin{array}{c}\text { Mode } \\
\mathrm{B}\end{array}$ & \\
\hline Con Campaign & n.s & & n.s. & & n.s. & \\
\hline Lab & -.2 & $(.067)$ & & $(.06$ & -.257 & $(.074)$ \\
\hline aign & .546 & ( & .4 & & .471 & \\
\hline Vote 2005 & $\mathrm{n} / \mathrm{a}$ & & 1.290 & $(.09$ & 1.209 & $(.104)$ \\
\hline Con & $\mathrm{n} / \mathrm{a}$ & & $\mathrm{n} / \mathrm{a}$ & & -.926 & (.133) \\
\hline Lab & $\mathrm{n} / \mathrm{a}$ & & $\mathrm{n} / \mathrm{a}$ & & n.s. & \\
\hline MiP & $\mathrm{n} / \mathrm{a}$ & & $\mathrm{n} / \mathrm{s}$ & & 1.845 & $(.130)$ \\
\hline Constant & -.466 & $(.047)$ & -.685 & $(.051)$ & -.779 & $(.061)$ \\
\hline Nagelkerke $R^{2}$ & .032 & & .104 & & .237 & \\
\hline-2 Log li & 4284.974 & & 4102.234 & & 3739.410 & \\
\hline
\end{tabular}

Note1: Standard Errors in parenthesis

Note 2: n.s. Not Statistically Significant

Note 3: $\quad \mathrm{n} / \mathrm{a}$ Not Applicable

Note 4: MiP Most Important Problem

Figure 6. Predicted probabilities of undecided respondents voting for a party by receipt of number of types of campaign material from that party, and previous support.

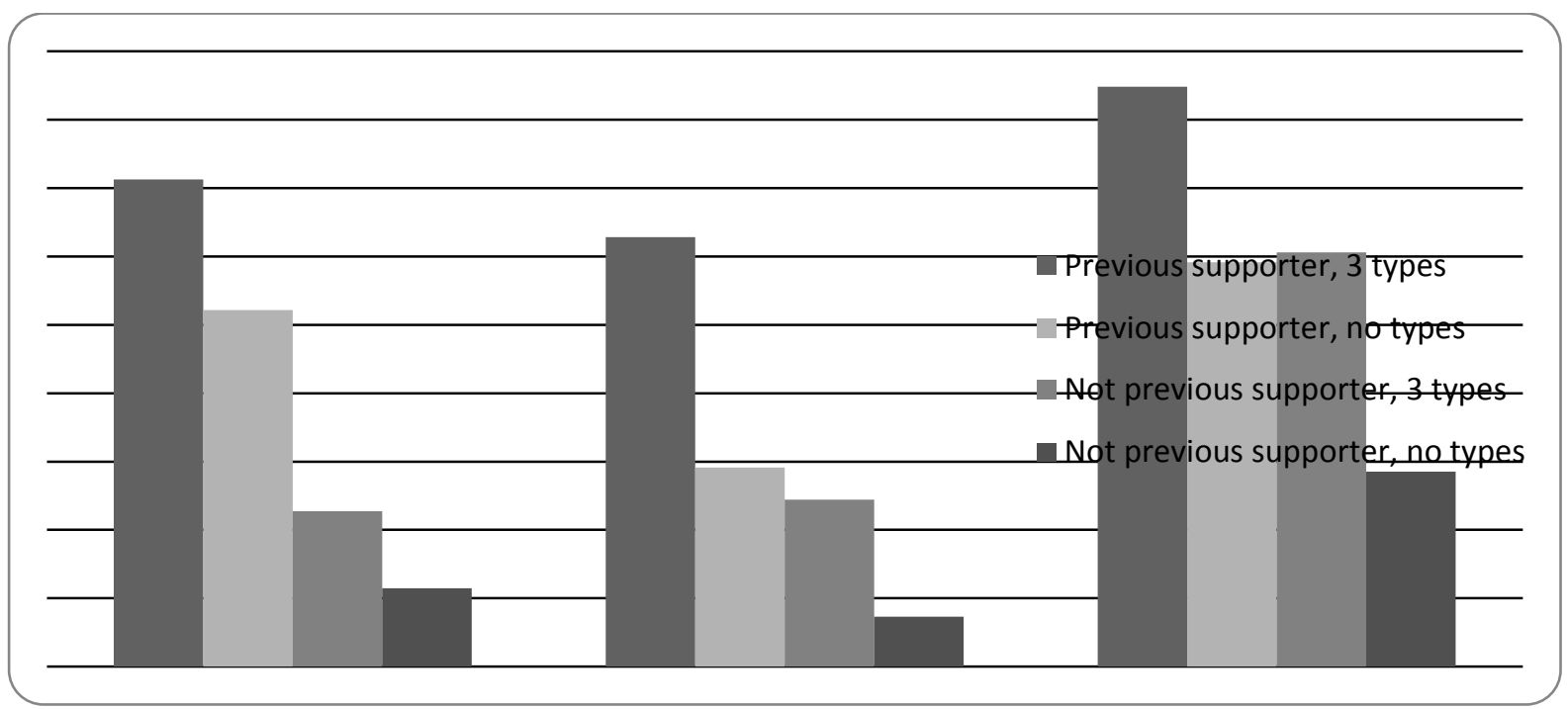

6. Discussion and Conclusions

In the 2010 general election, parties faced an uncertain electoral context. With Labour relatively unpopular, the potential was there for the Liberal Democrats to make further gains, provided that they could target their resources effectively, while resisting the resurgence of the Conservative Party. The picture for the Conservatives was mixed. The electoral momentum was with the party, but the arithmetic of gaining sufficient seats to win a majority was against them. For Labour, the picture was almost universally bad. Not only was the government unpopular, but their principal opponents were much stronger than five years previously, and through necessity the party was forced to target a large number of seats. Winning the election overall was unlikely, so minimizing losses was the focus. 
The outcomes in terms of the electoral payoffs from campaigning were mixed, but perhaps unexpected. The results for the Conservatives and the Liberal Democrats were generally positive, but not as positive as they might have been given the electoral context. In both cases, a plausible explanation is that there were too many targeted seats for the electoral payoffs to be as high as one might have expected. In the case of the Conservatives, this was understandable. An outright victory was possible, but only if the party gained at least 116 seats. Thus, the targeting of a large number of seats was a necessity given the results of the 2005 election. With the benefit of hindsight, less attention could, perhaps, have been paid to the party's 'certainties' - the very marginal seats that were likely to fall to the Conservatives anyway. As Figure 3 shows, relatively less intense campaigning occurred in these seats compared with the 'core targets' but given the marginality of these seats, more intense campaigning in the 'possibles' (which was of slightly lower intensity compared with the 'certainties') would probably have yielded stronger electoral payoffs. Of course, campaign planners would probably not have wanted to risk such a strategy. In any case, whether this effort could have been re-directed elsewhere is not clear. Indeed, for all parties, there is little benefit from campaigning less where the benefits are uncertain and resources are relatively immobile.

The Liberal Democrats, however, were probably both over ambitious and at the same time over cautious. In terms of ambition, the party possibly over-extended itself in terms of offensive targets. Previous elections have seen more modest targets in terms of gains reflecting the party's lower level of resource compared with the Conservatives and Labour. More problematic, however, was the defensive strategy in terms of existing Liberal Democrat seats, where as Figure 5 shows, there was virtually an identical level of intensity compared with the party's offensive targets. With the benefit of hindsight, much activity was expended unnecessarily, though the same caveats concerning mobility of resources apply here as to the Conservatives. In sum, while the Liberal Democrats were - as usual - very successful in differentiating campaign efforts between target and non-target seats, but like the Conservatives, it appears that their choice of targets was sub-optimal.

This becomes more apparent when we compare their results with those of Labour, whose campaigning was successful against the odds suggested by the electoral context. To help explain this, one might point to the relatively sophisticated way in which Labour target seats were designated (Fisher et al, 2011). Labour's targeting decisions were derived from propensity modelling. This technique applied four criteria: the level of activity in the local party, the electoral performance in various elections since 2005, the notional majority, and 
the existence of any particular political circumstances (such as hospital closures or expenses). All criteria were given a score with the model then predicting the result. The outcome was that Labour seemingly selected the most appropriate targets and had realistic assumptions about the result. Labour's strategy was to minimize its losses and deny the Conservatives a majority. The evidence here suggests that the party's constituency level campaigning was one contributory factor in its success. All of this tallies with previous work that has suggested that good central management of campaigns is as important - if not more important - than the level of raw resources on the ground (Fisher et al, 2006a).

These findings, then, are of some significance. In the first instance, they help explain why Labour was successful in denying the Conservative a majority despite securing its lowest post-war vote share save for that of 1983. Our model of campaign effectiveness (see Table 1) predicted correctly that the Conservative and Liberal Democrat campaigns would be more likely to be successful on account of closeness of the election and the likelihood of significant change. It also helps explain why the Conservatives may have been less successful due to problems of coordinating the necessarily large number of target seats. But on the face of it, it failed to explain why Labour's campaigns were relatively successful. To varying degrees, all of the variables in the model suggested that Labour's campaigns should have been less effective - Labour's unpopularity should have offset the impact of the closeness of the election and to a degree, the impact of the Conservatives' need to target so many seats. Equally, Labour's status as incumbent in an election where significant change was likely should have been to its disadvantage.

However, the findings suggest strong campaign management can help overcome such conditions to a degree. They emphasise that good campaign management really matters, and good management is about realism in respect of what a party can achieve. Thus, set against a group of very unfavourable variables, Labour was able to achieve its realistic objective of denying the Conservatives a majority. Compare this with the Conservative's strategy in 2001 of targeting 180 seats following the results of the 1997 election (Denver et al, 2002b). A better strategy then might well have been to focus on fewer seats to try and reduce Labour's majority. Good campaign management can then temper the effects of exogenous factors as much as less good campaign management can reduce their advantage. As such, in the light of these findings, our model as featured in Table 1 can be re-formulated (see Table 8). 
Table 8. New exogenous factors influencing likely effectiveness of constituency campaigns

$\begin{array}{llll} & \text { More Effective } & \text { Less Effective } \\ \text { Closeness of Election } & \text { Popularity Equilibrium } & \longleftrightarrow \text { Unpopular party(ies) } \\ \text { Significant change likely } & \text { Challenger(s) } & \longleftrightarrow \text { Incumbent } \\ \text { High No's of Target seats } & \text { Unpopular party(ies) } & \longleftrightarrow \text { Popularity Equilibrium } \\ \text { Central Management } & \text { Clear objectives } & \text { Unclear objectives }\end{array}$

So, management matters in predicting campaign success, but politics matters, too. Labour was conspicuously successful in recruiting undecided voters through its campaign efforts, which given Labour's difficulties in its third term points to a failing of both other parties (but particularly the Conservatives) to 'seal the deal' with the electorate. When Labour won in 1997, the party and its leader were both very popular in absolute terms. In 2010, Labour was unpopular, and the Conservatives were only popular in terms relative to Labour (Clarke et al., 2011: 252). In this context, Labour's campaigns were less likely to suffer from a tide of resignation and were more likely to be galvanised, both by the prospect of a Conservative victory and by the possibility in the short campaign that Labour could end up third in terms of vote share following the rapid improvement in Liberal Democrat poll ratings. Such successes were aided by very effective targeting. Labour, of course, lost the 2010 election, but the result of the constituency campaigns and their impact on the final outcome arguably points paradoxically to a form of 'triumph' for Labour against the odds. 


\section{References}

Arceneaux, K., Nickerson, D.W., 2009. Who is mobilized to vote? A Re-Analysis of Eleven Randomized Field Experiments. American Journal of Political Science 53 (1), 1-16.

Clarke, H.D., Sanders, D., Stewart, M.C., Whiteley, P., 2004, Political Choice in Britain. Oxford University Press, Oxford.

Clarke, H.D., Sanders, D., Stewart, M.C., Whiteley, P.F., 2009. Performance Politics and the British Voter. Cambridge University Press, Cambridge.

Clarke, H.D., Sanders, D., Stewart, M., Whiteley, P., 2011. Valence Politics and Electoral Choice in Britain, 2010. Journal of Elections, Public Opinion and Parties. 21 (2). 23753.

Cutts, D., 2006. Where we work we win' A Case study of Local Liberal Democrat Campaigning. Journal of Elections and Public Opinion, 16 (3), 221-42.

Cutts, D., Shryane, N., 2006. Did Local Activism Really Matter? Liberal Democrat Campaigning at the 2001 British General Election. British Journal of Politics and International Relations. 8 (3), 427-44.

Cutts, D., Webber, D. 2009. Voting Patterns, Party Spending and Relative Location in England and Wales. Regional Studies. 44 (6), 735-60.

Denver, D., Hands, G., 1997. Modern Constituency Electioneering. Frank Cass, London.

Denver, D., Hands, G., Fisher, J., MacAllister, I. 2002a. The Impact of Constituency Campaigning in the 2001 General Election. British Elections and Parties Review. 12, 80-94.

Denver, D., Hands, G., Fisher, J., MacAllister, I., 2002b. Constituency Campaigning in 2001: The Effectiveness of Targeting. In: Bartle, J., Mortimore R., Atkinson S. (Eds.), Political Communications: The British General Election of 2001. Frank Cass, London pp.159-80.

Denver, D., Hands, G., Fisher J., MacAllister I., 2003. Constituency Campaigning in Britain 1992-2001: Centralisation and Modernisation. Party Politics. 9 (5), 541-59.

Fieldhouse, E., Cutts, D., 2008. The Effectiveness of Local Party Campaigns in 2005: Combining Evidence from Campaign Spending and Agent Survey Data. British Journal of Political Science. 39 (2), 367-388.

Fisher, J., 2000. Small Kingdoms and Crumbling Organisations: Examining the Variation in Constituency Party Membership and Resources. British Elections \& Parties Review 10, 133-150.

Fisher, J., 2008. Whither the Parties? In: Hazell, R. (Ed.) Constitutional Futures Revisited, Palgrave, Basingstoke, pp. 249-66. 
Fisher, J. 2010. Party Finance - Normal Service Resumed? Parliamentary Affairs 63 (4), 778-801.

Fisher, J., Denver, D., Hands, G., 2006a. The Relative Electoral Impact of Central Party Coordination and Size of Party Membership at Constituency Level. Electoral Studies 25 (4), 664-76.

Fisher, J., Denver, D., Hands, G., 2006b. Party Membership and Campaign Activity in Britain: The Impact of Electoral Performance Party Politics 12 (4), 505-19.

Fisher, J., Denver, D., 2008. From Foot-Slogging to Call Centres and Direct Mail: A Framework for Analysing the Development of District-Level Campaigning. European Journal of Political Research 47 (6), 794-826.

Fisher, J., Denver, D. Fieldhouse, E., Cutts, D., Russell, A., 2005. Constituency Campaigning in the 2005 British General Election. Annual Conference of the American Political Science Association, Washington DC, 2005.

Fisher, J., Cutts, D., Fieldhouse, E., 2011. Constituency Campaigning in 2010. In: Wring, D., Mortimore R., Atkinson, S. (Eds.) Political Communication in Britain: TV Debates, the Media and the Election. Palgrave, Basingstoke, pp. 198-217.

Hillygus, D.S., 2005. Campaign Effects and the Dynamics of Turnout Intention in Election 2000. Journal of Politics 66(1), 50-68.

Holbrook, T. M., 1996. Do Campaigns Matter? Sage, London.

Katz, J.N., King, G., 1999. A statistical model for multiparty electoral data. American Political Science Review, 93 (1),15-32.

Niven, D., 2001. The Limits of Mobilization: Turnout Evidence from State House Primaries. Political Behavior 23(4), 335-50.

Pattie, C.J., Johnston, R.J., 2011. A Tale of Sound and Fury, Signifying Something? The Impact of the Leaders' Debates in the 2010 UK General Election. Journal of Elections, Public Opinion and Parties 21 (2), 147-77.

Pattie, C. J., Johnston, R. J., Fieldhouse, E. A., 1995. Winning the Local Vote: The Effectiveness of Constituency Campaign Spending in Great Britain, 1983-1992. American Political Science Review 89 (4), 969-83.

Stevens, D., Karp, J.A. , Hodgson, R., 2011 'Party Leaders as Movers and Shakers in British Campaigns? Results from the 2010 Election Journal of Elections, Public Opinion and Parties 21 (2), 125-45.

Tomz, M., Tucker, J.A., Wittenberg, J., 2002. An easy and accurate regression model for multiparty electoral data. Political Analysis 10 (1) 66-93.

Whiteley, P., Seyd, P., 1994. Local Party Campaigning and Voting Behaviour in Britain. Journal of Politics 56 (1) 242-51. 


\section{Appendix}

\section{Responses}

The numbers of responses for each party by target status were as follows:

\begin{tabular}{lcccc}
\hline & All & Held Not Target & Target & No Target Not Held \\
\hline Conservative & 287 & 120 & 56 & 111 \\
Labour & 388 & 129 & 74 & 185 \\
Liberal Democrat & 353 & $*$ & 50 & 303 \\
\hline
\end{tabular}

\section{Mean Percentage of Maximum Spend by Responses During Long and Short Campaigns}

\begin{tabular}{lrr}
\hline$\%$ & Respondents & All Constiuencies \\
\hline Conservative & 37.2 & 38.1 \\
Labour & 22.5 & 25.6 \\
Liberal Democrat & 18.8 & 19.6 \\
SNP & 17.0 & 16.3 \\
Plaid Cymru & 13.9 & 15.7 \\
\hline
\end{tabular}

\section{Calculation of Campaign Intensity Index}

Responses to the questions below are grouped through additive scales into the following core components of constituency campaigning: Preparation, Organisation, Manpower, Computers, Polling Day Activity, Telephones, Direct Mail, Canvassing, Leaflets and ECampaigning. These groups are then entered into a PCA, which produced the solution overleaf.

\begin{tabular}{ll}
\hline Group & Question \\
\hline Preparation & HOW PREPARED - JOBS \\
Preparation & HOW PREPARED - CAMPAIGN FUNDS \\
Preparation & HOW PREPARED - MAIN COMMITTEE ROOMS \\
Preparation & HOW PREPARED - LOCAL COMMITTEE ROOMS \\
Preparation & HOW PREPARED - ELECTORAL REGISTER \\
Preparation & HOW PREPARED - ELECTION ADDRESS \\
Preparation & HOW PREPARED - PRINTING \\
Preparation & HOW PREPARED - IDENTIFYING SUPPORTERS \\
Preparation & STARTED SERIOUS PLANNING \\
Preparation & USE OF PREVIOUS CANVASS RECORDS \\
Organization & \% OF CONST COVERED BY ACTIVE LOCAL ORGS \\
Organization & HOW LONG AGO KNEW RESPONSIBLE \\
Organization & DELEGATED DUTIES - CANVASSING ORGANISER \\
Organization & DELEGATED DUTIES - POSTAL VOTES \\
Organization & DELEGATED DUTIES - CANDIDATE AIDE \\
Organization & DELEGATED DUTIES - COMPUTER OFFICER \\
Organization & LOCAL ORGAINSERS OR SUB-AGENTS \\
Manpower & NUMBER OF CAMPAIGN WORKERS \\
Manpower & NUMBER OF CAMPAIGN HELPERS ON POLLING DAY \\
Computers & DELEGATED DUTIES - COMPUTER OFFICER \\
Computers & USE OF COMPUTERS - DIRECT MAIL \\
Computers & USE OF COMPUTERS - CANVASS RETURNS \\
Computers & USE COMPUTERISED ELECTORAL REGISTER \\
Computers & COMPUTERS USED TO COMPILE KNOCK-UP LISTS \\
Computers & ELECTION SOFTWARE PROVIDED BY PARTY HQ \\
Polling Day Activity & GOOD MORNING LEAFLETS DELIVERED \\
Polling Day Activity & VOTERS KNOCKED UP ON POLLING DAY \\
Polling Day Activity & \% OF CONSTITUENCY COVERED \\
&
\end{tabular}


Polling Day Activity Polling Day Activity Telephones

Telephones

Telephones

Telephones

Telephones

Direct Mail

Direct Mail

Canvassing

Canvassing

Leaflets

Leaflets

E-Campaigning

E-Campaigning E-Campaigning E-Campaigning E-Campaigning E-Campaigning E-Campaigning E-Campaigning E-Campaigning E-Campaigning E-Campaigning E-Campaigning
NUMBER OF CAMPAIGN HELPERS ON POLLING DAY

VOLUNTEERS SENT INTO YOUR CONSTITUENCY

USE TELEPHONE CANVASSING IN CONSTITUENCY

OUTSIDE CANVASSING

USE TELEPHONE CANVASSING

TELEPHONE CANVASSING ORGANISED FROM OUTSIDE CONSTITUENCY

VOTERS CONTACTED BY TELEPHONE ON POLLING DAY

LEAFLETS TARGETED AT PARTICULAR GROUPS

DIRECT MAIL USED TO TARGET INDIVIDUAL VOTERS

$\%$ OF ELECTORATE CANVASSED

$\%$ OF ELECTORATE TELEPHONE CANVASSED?

HOW MANY REGIONALLY/NATIONALLY PRODUCED LEAFLETS DISTRIBUTED

TOTAL NUMBER OF LOCALLY PRODUCED LEAFLETS

PRE-ELECTION CAMPAIGN - OPERATING AND MAINTAINING A WEBSITE

PRE-ELECTION CAMPAIGN - USING SOCIAL NETWORKING SITES

CONTACT VOTERS IN THE CONSTITUENCY BY TEXT MESSAGE

MAKE USE OF TWITTER TO COMMUNICATE WITH VOTERS

USE OF COMPUTERS - EMAILING VOTERS

LOCAL PARTY \& CANDIDATE WEBSITE

CAMPAIGN EFFORT - MAINTAINING WEBSITE

CAMPAIGN EFFORT - EMAILING VOTERS

CAMPAIGN EFFORT - SOCIAL NETWORKING SITES

CAMPAIGN EFFORT - VIDEO/IMAGE SHARING SITES

VOTERS CONTACTED BY TEXT ON POLLING DAY

VOTERS CONTACTED BY EMAIL ON POLLING DAY

\section{Principal Components Analysis of Campaign Components}

\begin{tabular}{lr}
\hline & Component \\
& 1 \\
\hline PREPARATION & .816 \\
ORGANISATION & .775 \\
MANPOWER & .641 \\
COMPUTERS & .507 \\
POLLING DAY ACTIVITY & .824 \\
TELEPHONES & .765 \\
DIRECT MAIL & .740 \\
CANVASSING & .719 \\
LEAFLETS & .438 \\
E-CAMPAIGNING & .475 \\
\hline
\end{tabular}

Extraction Method: Principal Component Analysis.

a 1 components extracted. 
Table A1. The Impact of Campaign Contacts on Previously Undecided Voters (with leadership evaluations)

\begin{tabular}{|l|rl|rl|rl|}
\hline$n=3048$ & \multicolumn{2}{|c|}{ Conservative } & \multicolumn{3}{|c|}{ Labour } & \multicolumn{3}{|c|}{ Lib Dems } \\
& $\mathrm{B}$ & $\mathrm{B}$ & $\mathrm{B}$ & \\
\hline Con Campaign & .298 & $(.090)$ & $\mathrm{n} . \mathrm{s}$. & & $\mathrm{n} . \mathrm{s}$ & \\
Lab Campaign & $\mathrm{n} . \mathrm{s}$. & & .401 & $(.088)$ & -.311 & $(.078)$ \\
Lib Dem Campaign & -.366 & $(.106)$ & -.418 & $(.109)$ & .471 & $(.081)$ \\
Con Vote 2005 & 1.277 & $(.131)$ & $\mathrm{n} / \mathrm{a}$ & & $\mathrm{n} / \mathrm{a}$ & \\
Lab Vote 2005 & $\mathrm{n} / \mathrm{a}$ & & 1.229 & $(.104)$ & $\mathrm{n} / \mathrm{a}$ & \\
Lib Dem Vote 2005 & $\mathrm{n} / \mathrm{a}$ & & $\mathrm{n} / \mathrm{a}$ & & 1.194 & $(.110)$ \\
Con MiP & 1.016 & $(.140)$ & -.604 & $(.226)$ & -.612 & $(.146)$ \\
Lab MiP & -.655 & $(.242)$ & .629 & $(.129)$ & -.374 & $(.127)$ \\
Lib Dem MiP & -1.032 & $(.219)$ & -.797 & $(.186)$ & 1.410 & $(.137)$ \\
Gordon Brown Evaluation & -.171 & $(.024)$ & .317 & $(.024)$ & $\mathrm{n} . \mathrm{s}$. & \\
David Cameron Evaluation & .393 & $(.029)$ & -.123 & $(.022)$ & -.146 & $(.018)$ \\
Nick Clegg Evaluation & -.167 & $(.027)$ & -.18 & $(.025)$ & .258 & $(.022)$ \\
Constant & -1.939 & $(.201)$ & -1.927 & $(.192)$ & -1.604 & $(.163)$ \\
Nagelkerke R & .482 & & .386 & & .311 & \\
-2 Log likelihood & 2124.849 & & 2363.018 & & 3337.355 & \\
\hline
\end{tabular}

Note1: Standard Errors in parenthesis

Note 2: n.s. Not Statistically Significant

Note 3: n/a Not Applicable

Note 4: MiP Most Important Problem 